\title{
溶融 Agによる固体酸化物の濡れ性に及ぼす溶解酸素の影響
}

\author{
泰 松 斉* 阿 部 倫比古**

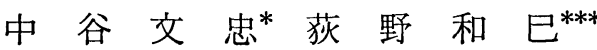

J. Japan Inst.Metals, Vol.49, No.7(1985), pp.523-528

Effect of Soluble Oxygen on the Wettability of Solid Oxides

by Liquid Silver

Hitoshi Taimatsu*, Michihiko Abe**, Fumitada Nakatani* and Kazumi Ogino***

\begin{abstract}
The surface tensions of liquid Ag-O alloys and the contact angles between liquid $\mathrm{Ag}-\mathrm{O}$ alloys and solid oxides were measured in $\mathrm{Ar}+\mathrm{O}_{2}$ mixture at $1273 \mathrm{~K}$ by the sessile drop method. Polycrystalline alumina, single-crystal alumina and fused quartz were used as the solid oxides. Oxygen is highly surface active and the maximum surface excess of oxygen is $5.8 \times 10^{-6} \mathrm{~mol} \cdot \mathrm{m}^{-2}$. The wettability of polycrystalline alumina, single-crystal alumina and fused quartz byl iquid $\mathrm{Ag}-\mathrm{O}$ alloys increased with increasing oxygen partial pressure. In the case of fused quartz which was most strongly wetted by liquid $\mathrm{Ag}-\mathrm{O}$ alloys in high oxygen partial pressure, a reacted layer was observed in the interface. In this layer, metallic $\mathrm{Ag}$ particles less than $0.5 \mu \mathrm{m}$ in size dispersed.
\end{abstract}

(Received April 5, 1985)

Keywords : surface tension, wettability of solid oxides, contact angle, surface-active element, liquid silver-oxygen alloy, alumina, fused quartz

\section{I. 緒言}

酸素は溶融金属の表面張力や固体酸化物との界面張力を 微量の添加で著しく低下させ，溶融金属による固体酸化物 の濡れを促進させる作用がある，このため，濡れる方が好 ましい場合，たとえば金属とセラミックスを直接接合させ る際には, 酸素の添加は濡れ性を増加させ, セラミックス との密着性を向上させる。乙かし，溶融金属を酸化物ルッ ボ中で溶解する際には，ルッボを保護するために金属中の 酸素を減らし濡れにくくする必要がある。このような観点 から，溶融金属による固体酸化物の濡れ性に及ぼす酸素の 影響について知ることは工業的に重要であると考えられ る.しかし酸素量の変化による濡れ性の変化の仕方は金属 や固体酸化物の種類によってそれぞれ巽なり，統一的に理 解するためには多くの系について調べる必要がある。これ まで溶融金属 - 酸素系による固体酸化物の濡れ性について は $\mathrm{Fe}-\mathrm{O} / \mathrm{Al}_{2} \mathrm{O}_{3}$ 系(1)(2), $\mathrm{Cu}-\mathrm{O} / \mathrm{Al}_{2} \mathrm{O}_{3}$ 系 ${ }^{(3)(4)}, \mathrm{Ni}-\mathrm{O} / \mathrm{Al}_{2} \mathrm{O}_{3}$ 系 ${ }^{(5)}, \mathrm{Co}-\mathrm{O} / \mathrm{Al}_{2} \mathrm{O}_{3}$ 系 ${ }^{(6)}, \mathrm{Co}-\mathrm{Fe}-\mathrm{O} / \mathrm{Al}_{2} \mathrm{O}_{3}$ 系 ${ }^{(6)}$ で詳しい報 告があるが, $\mathrm{Cu}-\mathrm{O} / \mathrm{Al}_{2} \mathrm{O}_{3}$ 系を除いていずれの場合も $\mathrm{Fe}$ 族の金属に関するものである。したがって本研究では，溶
融金属による固体酸化物の濡れ性に及ぼす酸素の影響を調 ベる一環として，Cu と同族元素である $\mathrm{Ag}$ に着目し，溶 融 $\mathrm{Ag}-\mathrm{O}$ 合金の表面張力ならびに多結晶 $\mathrm{Al}_{2} \mathrm{O}_{3}$, 単結晶 $\mathrm{Al}_{2} \mathrm{O}_{3}$, 透明石英との接触角を測定し濡れ性に及ぼす酸素 の影響について検討する.

\section{II. 実験}

\section{1. 試料}

$\mathrm{Ag}$ 試料は, 市販の顆粒状 $\mathrm{Ag}$ (半井化学, $99.99 \%$ )を高 純度 $\mathrm{Al}_{2} \mathrm{O}_{3}$ ボートに入れ, 浄化した $\mathrm{H}_{2}$ 気流中で溶解し凝 固させ, その鋳塊から棒状に約 $2.5 \mathrm{~g}$ 切り出し, 表面研磨 後脱脂して作製した.

固体酸化物試料として多結晶 $\mathrm{Al}_{2} \mathrm{O}_{3}$, 単結晶 $\mathrm{Al}_{2} \mathrm{O}_{3}$, 透 明石英を用いたが，そのうち多結晶 $\mathrm{Al}_{2} \mathrm{O}_{3}$ は市販の焼結 $\mathrm{Al}_{2} \mathrm{O}_{3}$ (戸田超耐火物, $\mathrm{SA}-\mathrm{II}$, 直径 $25 \mathrm{~mm}$, 厚さ $5 \mathrm{~mm}$ ) をまずカーボランダム（\#1500）を用いて入念に研磨したの ち, 酸洗, 超音波洗浄後, 約 $1100 \mathrm{~K}$ で空焼して測定に供 した。また単結晶 $\mathrm{Al}_{2} \mathrm{O}_{3}$ (東芝セラミックス, 直径 $20 \mathrm{~mm}$, 厚さ $1 \mathrm{~mm}$ ) 扎よび透明石英(東芝セラミックス, 直径 25

* 秋田大学鉱山学部治金学科 (Department of Metallurgy, Mining College, Akita University, Akita)

** 秋田大学鉱山学部学生, 現在 : 山岡工業株式会社 (Undergraduate Student, Akita University, Akita. Present address : Yamaoka-Kogyo Co. Ltd., Akita)

*** 大阪大学工学部冶金工学科 (Department of Metallurgical Engineering, Faculty of Engineering, Osaka University, Suita) 
$\mathrm{mm}$ ，厚さ $3 \mathrm{~mm}$ ) はいずれも鏡面仕上したものをそのまま 使用した。

\section{2. 実験装置ならびに方法}

測定に使用した電気炉の 概略を Fig.1 に示す，測定装 置は $\mathrm{SiC}$ 棒状発熱体を用いた水平調節が可能な電気炉と, カメラ (日本光学, ニコマート FTN) にベローズを介して $200 \mathrm{~mm}$ 望遠レンズを装着した写真撮影装置から構成され ている。

まず炉の均熱部に較正した水準器を用いて固体酸化物試 料を水平に設置後, 試料滴下装置内に $\mathrm{Ag}$ 試料を'装入し, 炉の低温部に位置させた。ついで純 $\mathrm{Ag}$ の測定では脱水し た $\mathrm{Ar}-5 \% \mathrm{H}_{2}$ 混合ガスを，また $\mathrm{Ag}-\mathrm{O}$ 合金の測定では $\mathrm{Ar}$ $\mathrm{O}_{2}$ 混合ガスを Fig.2 に示す回路で炉内に流入し, 約 $7.2 \mathrm{ks}$ 間置換したのち昇温した. 所定温度に到達後, 低温部の試料 滴下装置を固体酸化物試料直上に移動させ, 溶解後静かに 滴下した。金属滴が試料台上に静止するとただちに写真撮 影を行い, $0.3 \mathrm{ks}$ 間隔で $2.4 \mathrm{ks}$ 間撮影したのち試料を急 冷した。

表面張力および接触角の值は撮影したフィルムより試料 滴の形状を計測し算出した。計算に際しては Bashforth と Adams の表 ${ }^{(7)}$ を用いる方法は表の検索が繁雑であるため, 静滴の釣り合いに関する Laplace の方程式をRunge-Kutta 法により数值計算し，測定した滴の形状に一致するように 収束計算した時の值をその静滴の表面張力および接触角の

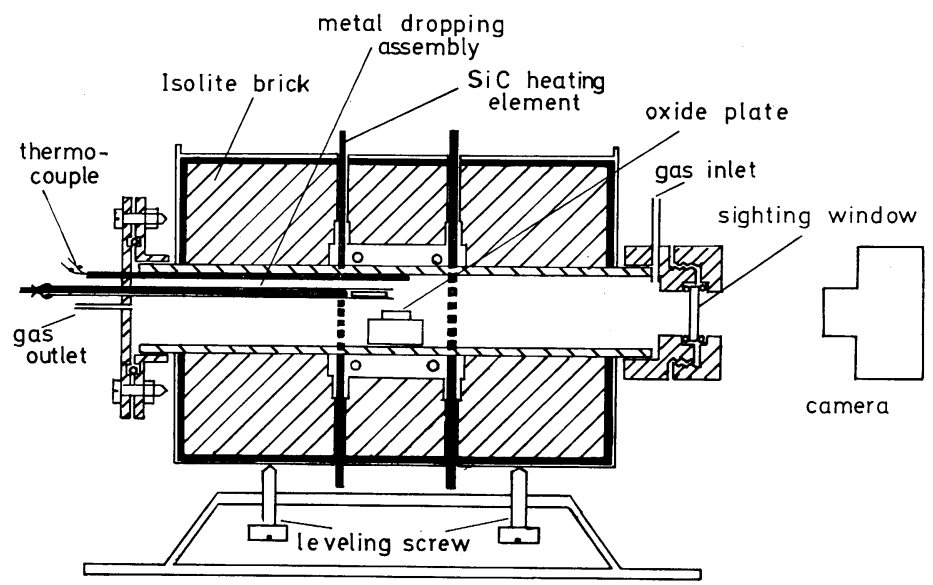

Fig.1 Apparatus for measurements of surface tension and contact angle.

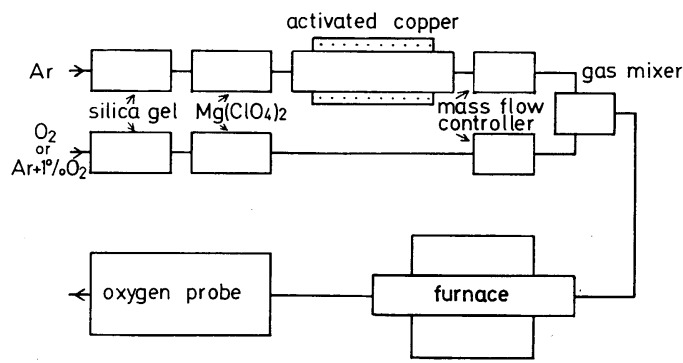

Fig.2 Schematic diagram of gas circuit.
值とした。この方法による数値計算結果は Bashforth と Adams の表による計算值と一致した。

なお, $\mathrm{Ar}-\mathrm{O}_{2}$ 混合ガスの酸素分圧測定は $\mathrm{ZrO}_{2}-11 \mathrm{~mol} \%$ $\mathrm{CaO}$ 固体電解質酸素プローブを用いて行ったが, $\mathrm{Ar}$ ガス はガス自体に酸素に対する緩衝能力がないため，酸素分圧 が高い場合にはガス流速の影響を受けないが，低い場合に は流速の変動により酸素分圧が変化する ${ }^{(8)}(9)$. 本実験の場 合, 酸素分圧が $10 \mathrm{~Pa}$ 付近では若干のガス流速依存性が認 められた。 したがって酸素分圧が 10〜100 Pa の測定では ガス流速に依存しない領域である $3.3 \times 10^{-6} \mathrm{~m}^{3} \cdot \mathrm{s}^{-1}$ のガス 流速で，また酸素分圧が $100 \mathrm{~Pa}$ 以上ではガス流速依存性 が認められなかったので $1.7 \times 10^{-6} \mathrm{~m}^{3} \cdot \mathrm{s}^{-1}$ のガス流速で測 定を行った。

\section{III. 結 果}

\section{1. 溶融 $\mathbf{A g - 0}$ 合金の表面張力}

溶融 $\mathrm{Ag}-\mathrm{O}$ 合金の表面張力を種々の酸素分圧に調整した $\mathrm{Ar}-\mathrm{O}_{2}$ ガス中, $1273 \mathrm{~K}$ で静滴法によって測定した．溶融 $\mathrm{Ag}$ 中の 酸素含有量は Sievert の法則に従うので(10), 溶融 $\mathrm{Ag}$ の表面張力を酸素含有量のかわりに䨌囲気の酸素分圧 の平方根で整理した結果を Fig.3に示す。それぞれの表 面張力值は $\mathrm{Ar}-\mathrm{O}_{2}$ ガス中の酸素と平衡して一定値を示し た $1.2 \mathrm{ks}$ 以後の測定值を平均したものである，表面張力 の計算に必要な密度值は文献値間(11) に良好な一致が見ら れるので, 本実験の滴の形状と試料重量から直接求まる密 度の值は滴の回転対称性の検討に用い, 表面張力の計算には Lucas の測定値 $9.29 \mathrm{Mg} \cdot \mathrm{m}^{-3(11)}$ を用いた。

溶融 $\mathrm{Ag}$ の表面張力は気相の酸素分圧 の増加にしたがって, 純 $\mathrm{Ag}$ の場合の $892 \mathrm{mN} \cdot \mathrm{m}^{-1}$ から急激に低下し, 酸素分 圧が $7 \times 10^{3} \mathrm{~Pa}$ 以上になるとほとんど酸 素分圧に依存せず一定となった，本測定 結果はBernard と Lupis ${ }^{(12)}$ の測定結果 と非常に良く一致したが, Eremenko と Naidich ${ }^{(13)}$ の測定結果とは一致しなかっ た。

\section{2. 溶融 $\mathrm{Ag}-\mathrm{O}$ 合金と固体酸化物間 の接触角}

$1273 \mathrm{~K}$ に打ける溶融 $\mathrm{Ag}-\mathrm{O}$ 合金と多結晶 $\mathrm{Al}_{2} \mathrm{O}_{3}$, 単結晶 $\mathrm{Al}_{2} \mathrm{O}_{3}$ および透明石英間の接触角を Fig. 4 に示す．多結晶 $\mathrm{Al}_{2} \mathrm{O}_{3}$ の場合，接触角は純溶融 $\mathrm{Ag}$ の場合の $160^{\circ}$ から酸素 分圧の増加にしたがって減少し，約 $10^{4} \mathrm{~Pa}$ 以上でほぼ一定 になる傾向があった，それに対して単結晶 $\mathrm{Al}_{2} \mathrm{O}_{3}$ の場合は 酸素分圧の増加にしたがって $130^{\circ}$ からゆるやかに低下し, 多結晶 $\mathrm{Al}_{2} \mathrm{O}_{3}$ に比べていずれの酸素分圧下でも相対的に $20^{\circ} \sim 30^{\circ}$ 低い值を示した，透明石英の場合は酸素分圧の 増加に対する接触角の变化の仕方が単結晶 $\mathrm{Al}_{2} \mathrm{O}_{3}$ の場合と 


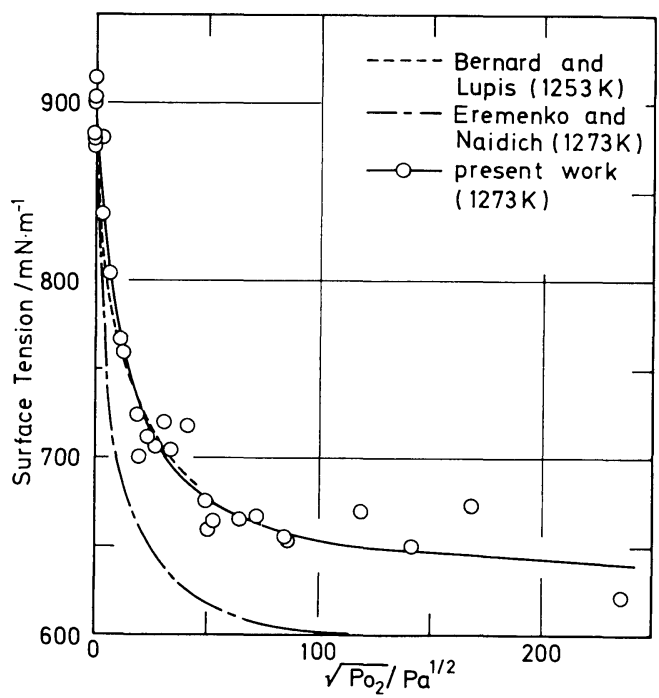

Fig.3 Surface tension of liquid Ag-O alloys at $1273 \mathrm{~K}$.

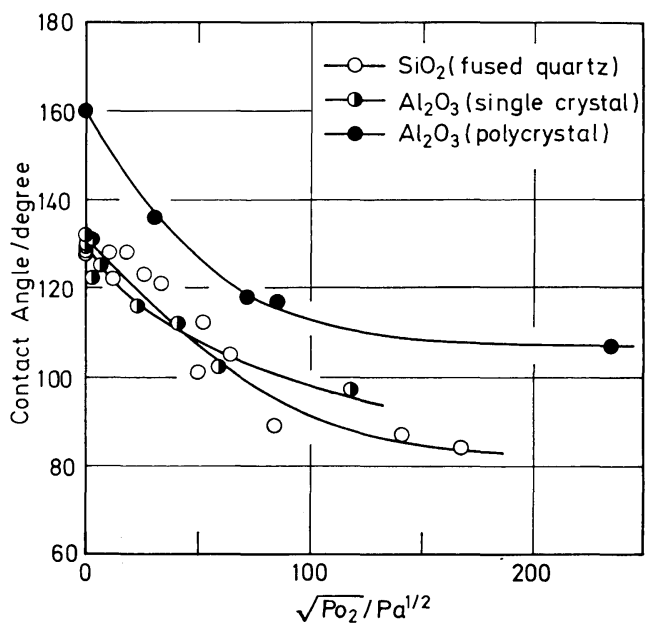

Fig. 4 Contact angles between liquid $\mathrm{Ag}-\mathrm{O}$ alloys and solid oxides at $1273 \mathrm{~K}$.

よく似ているが，低下の仕方がやや大きく，約 $10^{4} \mathrm{~Pa}$ 以 上の酸素分圧で接触角が $90^{\circ}$ 以下になった。測定を行った 多結晶 $\mathrm{Al}_{2} \mathrm{O}_{3}$, 単結晶 $\mathrm{Al}_{2} \mathrm{O}_{3}$, 透明石英の中で, どの酸素分 圧下に执いても最も接触角が高いのは多結晶 $\mathrm{Al}_{2} \mathrm{O}_{3}$ で, 単 結晶 $\mathrm{Al}_{2} \mathrm{O}_{3}$ と透明石英はいずれも多結晶 $\mathrm{Al}_{2} \mathrm{O}_{3}$ に比べて 接触角が低く，酸素分圧が $4 \times 10^{3} \mathrm{~Pa}$ 以上では透明石英が 最も濡れやすかった。

\section{3. 溶融 Ag-0 合金と固体酸化物間の付着の仕事}

濡れ性を評価するためには，単に接触角の比較のみなら ず，付着の仕事を算出し付着力を評価する必要がある．液 体と固体を引き離すのに必要な付着の仕事, $W_{\mathrm{ad}}\left(\mathrm{mJ} \cdot \mathrm{m}^{-2}\right)$ は液体金属の表面エネルギー， $\gamma_{1}\left(\mathrm{~mJ} \cdot \mathrm{m}^{-2}\right)$ と接触角， $\theta$ (degree) によって

$$
W_{\text {ad }}=\gamma_{1}(1+\cos \theta)
$$

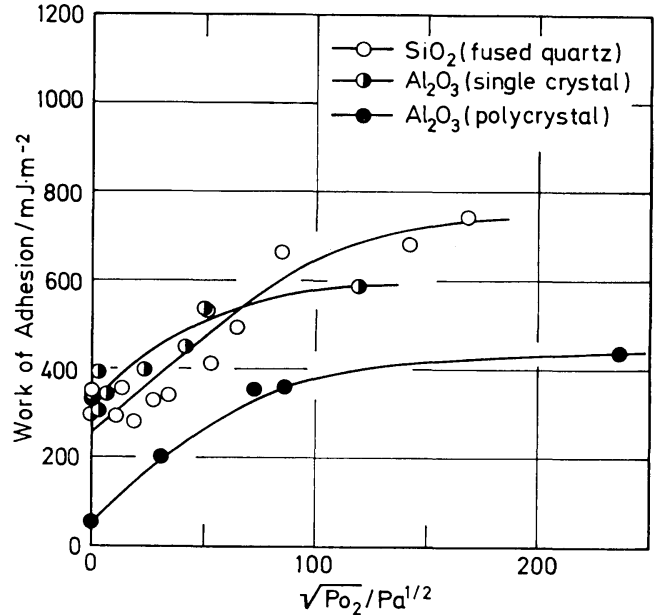

Fig. 5 Works of adhesion between liquid Ag-O alloys and solid oxides at $1273 \mathrm{~K}$.

と表わされる．Fig.5 と各酸素分圧下での溶融 Ag-O 合金 と多結晶 $\mathrm{Al}_{2} \mathrm{O}_{3}$, 単結晶 $\mathrm{Al}_{2} \mathrm{O}_{3}$ 扩よび透明石英間の付着の 付事を示す。いずれの固体酸化物の場合も溶融 $\mathrm{Ag}-\mathrm{O}$ 合金 との付着の仕事は酸素分圧が高くなるにつれて著しく増加 するが，特に酸素分圧が $5 \times 10^{3} \mathrm{~Pa}$ 以上では透明石英が最 も大きな值を示した。また多結晶 $\mathrm{Al}_{2} \mathrm{O}_{3}$ と単結晶 $\mathrm{Al}_{2} \mathrm{O}_{3}$ を 比較すると, 単結晶 $\mathrm{Al}_{2} \mathrm{O}_{3}$ の方がどの酸素分圧下でる相対 的に $200 \mathrm{~mJ} \cdot \mathrm{m}^{-2}$ 程度大きかった。

\section{4. 凝固後試料の界面観察}

測定後急冷した試料を $\mathrm{Ag}$ /固体酸化物界面に対して垂直 になるように切断し, 研磨したのち, 光学顕微鏡を用いて 観察した結果，多結晶拉よび単結晶 $\mathrm{Al}_{2} \mathrm{O}_{3}$ の場合にはどの 酸素分圧下で実験を行った試料飞打いても界面に明膫な反 応層は認められず，非常に平滑な界面を呈していた。しか し高酸素分圧下で最も接触角が低い透明石英の場合は, 酸 素分圧が $7 \times 10^{3} \mathrm{~Pa}$ 以上になると $\mathrm{Ag} /$ 透明石英界面に厚 さ $5 \sim 7 \mu \mathrm{m}$ の薄茶色の反応層の存在が認められた。この

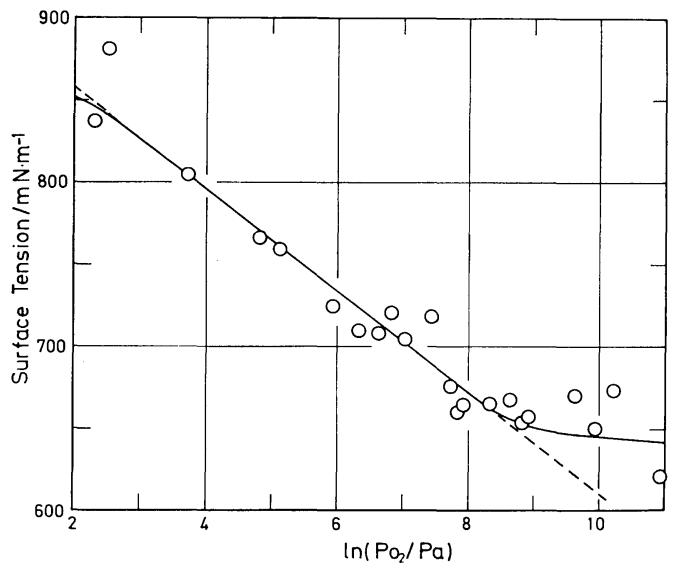

Fig.6 Relation between the surface tension of liquid $\mathrm{Ag}-\mathrm{O}$ alloys and $\ln \left(\mathrm{P}_{\mathrm{O}_{2}} / \mathrm{Pa}\right)$. 
層を詳しく調べるために EPMA（日本電子，JXA-733)を 用いて観察した結果を Fig.6に示す. $\mathrm{Ag}$ と透明石英の間 に存在する反応層内には $0.5 \mu \mathrm{m}$ 以下の微細な粒が 観察さ れた。この粒には対応する特性 X線から $\mathrm{Ag}$ が多量に含ま れて招り，また反応層内の基地部分には Si 拈よびOが存 在していた，さらにこの反応層の基地と析出粒の組成を明 らかにするために，加速電圧 $10 \mathrm{kV}$ で，できる限りビーム 径を小さくして析出粒の認められない基地部分と最も大き な析出粒の 2 箇所の定量分析を行った．得られた相対 X線 強度を原子番号補正, 吸収補正ならびにけい光補正し定量 化した，その結果，反応層内の基地部分は $\mathrm{SiO}_{2}$ ，また析出 粒は $\mathrm{Ag}$ で, 反応層は $\mathrm{SiO}_{2}$ に微細な $\mathrm{Ag}$ 粒子が分散した 層であることが明らかになった。

\section{IV. 考察}

\section{1. 溶融 $\mathrm{Ag}$ 表面における酸素の吸着}

表面に打ける溶質成分の吸着量と表面張力の関係は，希 薄溶液の場合, Gibbs の等温吸着式によって,

$$
\Gamma=-\frac{\mathrm{d} \gamma_{1}}{\mathrm{~d} \mu_{0}}
$$

と表わされる。ここで $\Gamma$ は表面過剰量 $\left(\mathrm{mol} \cdot \mathrm{m}^{-2}\right), \gamma_{1}$ は液 体の表面張力 $\left(\mathrm{N} \cdot \mathrm{m}^{-1}\right), \mu_{0}$ は溶解した酸素の化学ポテン シャル $\left(\mathrm{J} \cdot \mathrm{mol}^{-1}\right)$ である。溶融 $\mathrm{Ag}$ 中の酸素は Sievert の
法則にしたがって溶解する(10)ので， $R$ をガス定数， $T$ を 絶対温度とした時, 式 (1)は

$$
\Gamma=-\frac{2}{R T} \cdot \frac{\mathrm{d} \gamma_{1}}{\mathrm{~d} \ln P_{\mathrm{O}_{2}}}
$$

となる、

式 (3)を用いて溶融 $\mathrm{Ag}$ 表面に拈ける酸素の表面過剰量 を求めるために溶融 $\mathrm{Ag}$ の表面張力を $\ln P_{\mathrm{O}_{2}}$ に対して整 理した結果を Fig.7 に示す。図中の破線は最大傾斜に相 当し, 最大表面過剩量を与える。この部分より酸素分圧が 高くなると傾斜はゆるやかになるが，このような傾向は溶 融金属に対する表面活性元素の吸着の際の一般的傾向であ る。図中の破線部の傾きより最大表面過利量を計算する と $5.8 \times 10^{-6} \mathrm{~mol} \cdot \mathrm{m}^{-2}$ であった。この值は Eremenko と Naidich の測定値 $30 \times 10^{-6} \mathrm{~mol} \cdot \mathrm{m}^{-2}(1273 \mathrm{~K}){ }^{(13)}$ とは全く 異なるが，Bernard と Lupis の測定值 $4.8 \times 10^{-6} \mathrm{~mol} \cdot \mathrm{m}^{-2}$ $(1253 \mathrm{~K}), 4.5 \times 10^{-6} \mathrm{~mol} \cdot \mathrm{m}^{-2}(1381 \mathrm{~K}){ }^{(12)}$ とほぼ一致する.

Kozakevitch とUrbain ${ }^{(1)}$ は溶融 Fe に対する $\mathrm{O}, \mathrm{S}, \mathrm{Se}$ の吸着を検討し，O，S, Se は電気二重層を形成しながら表 面の第一層に並び，その配列は固体鉄カルコゲン化物の結 晶面の中で, O, S , Se のみで形成する最稠密な面の配列で あるとした。このモデルは溶融 $\mathrm{Fe}$ 以外に同じ鉄族である $\mathrm{Ni}$, Co に対する酸素の吸着の際にもよく当てはまること をすでに著者らは報告した(5)(6)。このモデルを $\mathrm{Ag}-\mathrm{O}$ 系に

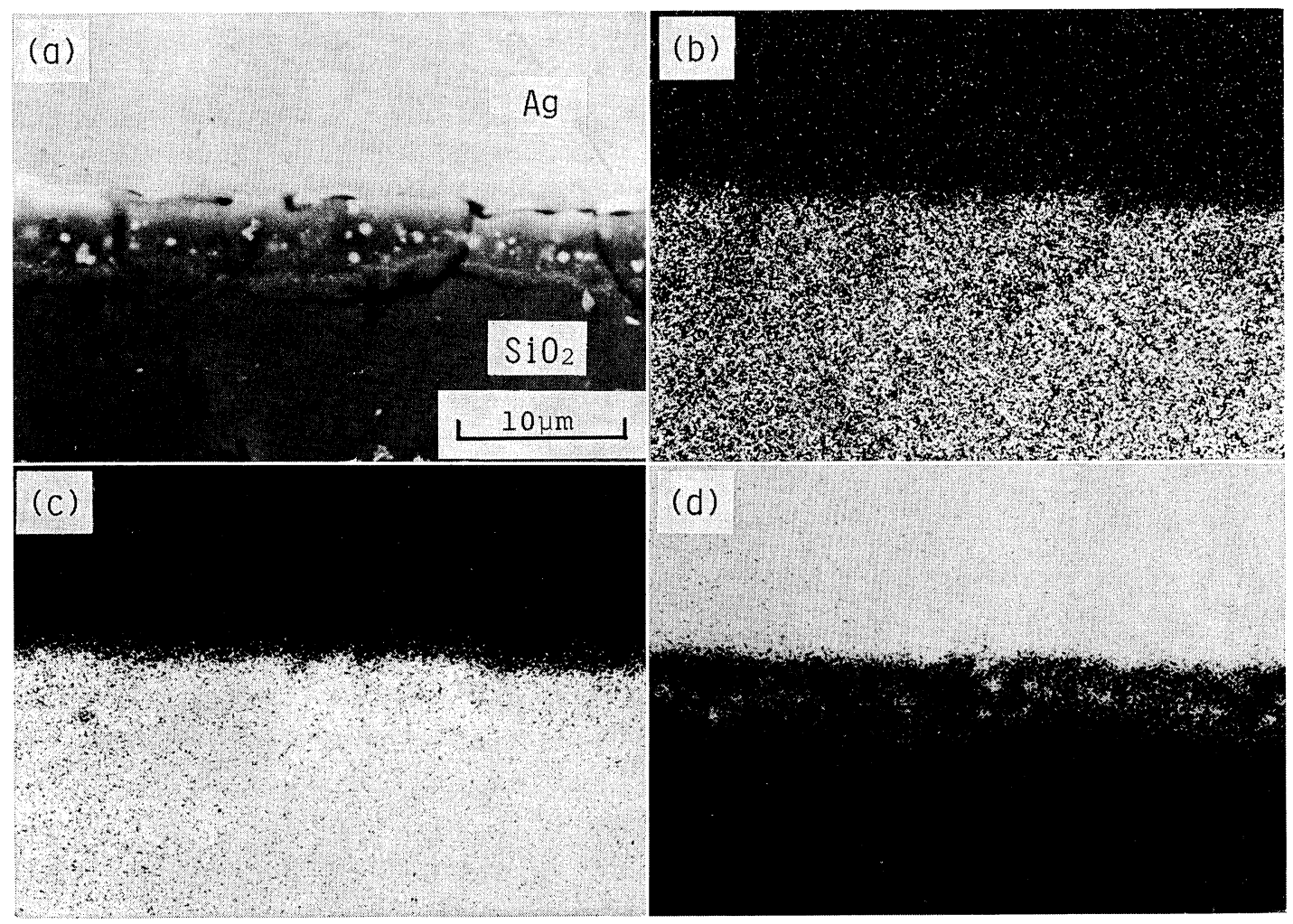

Fig.7 X-ray microanalysis of $\mathrm{Ag}-\mathrm{O}$ alloy/fused quartz interface having reacted at $1273 \mathrm{~K}$ in oxygen pressure of $2.84 \times 10^{4} \mathrm{~Pa}$.
(a) Secondary electron image.
(b) $\mathrm{O} \cdot \mathrm{K} \alpha$ image.
(c) $\mathrm{Si} \cdot \mathrm{K} \alpha$ image.
(d) $\mathrm{Ag} \cdot \mathrm{L} \alpha$ image. 
適用すると, 相当するカルコゲン化物は $\mathrm{Ag}_{2} \mathrm{O}$ である. $\mathrm{Ag}_{2} \mathrm{O}$ は赤銅鉱型構造であるため, 酸素のみで形成する最 稠密面は (100) 面である. $\mathrm{Ag}_{2} \mathrm{O}$ の格子定数は $0.473 \mathrm{~nm}^{(14)}$ であるからこの結晶面 $1 \mathrm{~m}^{2}$ 当りに並んでいる酸素のモ ル数を計算すれば, $7.4 \times 10^{-6} \mathrm{~mol} \cdot \mathrm{m}^{-2}$ である。この計算 值は測定値が表面張力の微分量であるため誤差が大きいこ とを考慮すれば測定値とほぼ一致しているものと思われ る.

一方 $\mathrm{Ag}$ と同族元素である $\mathrm{Cu}$ について検討すると, $\mathrm{Cu}_{2} \mathrm{O}$ は $\mathrm{Ag}_{2} \mathrm{O}$ と同じ赤銅鉱型構造であるため,酸素のみで 形成する最稠密は $\mathrm{Cu}_{2} \mathrm{O}$ の $(100)$ 面である. 格子定数は 0.427 $\mathrm{nm}$ (14) であるから，モデルによる計算值は $9.1 \times 10^{-6} \mathrm{~mol}$. $\mathrm{m}^{-2}$ となり，報告されている測定值， $5.72 \times 10^{-6} \mathrm{~mol} \cdot \mathrm{m}^{-2}$ $(1381 \mathrm{~K})^{(15)}$ とは少し異なるが, $9.3 \times 10^{-6} \mathrm{~mol} \cdot \mathrm{m}^{-2}(1423$ $\mathrm{K}), 10.4 \times 10^{-6} \mathrm{~mol} \cdot \mathrm{m}^{-2}(1503 \mathrm{~K}), 11.5 \times 10^{-6} \mathrm{~mol} \cdot \mathrm{m}^{-2}$ $(1573 \mathrm{~K})^{(16)}$ とよく一致する。

Kozakevitch とUrbain のモデルでは酸素の吸着の場 合，相当する金属酸化物の構造が同じ金属では同じ吸着形 態になることが予想される。したがって，同族元素である $\mathrm{Ag}$ と $\mathrm{Cu}$ は, 酸化物 $\mathrm{Ag}_{2} \mathrm{O}$ と $\mathrm{Cu}_{2} \mathrm{O}$ の構造が同じであるた め, 酸素の吸着の仕方が類似しているものと考えられる.

\section{2. 溶融 $\mathbf{A g - O}$ 合金による固体酸化物の濡れ性}

多結晶 $\mathrm{Al}_{2} \mathrm{O}_{3}$, 単結晶 $\mathrm{Al}_{2} \mathrm{O}_{3}$, 透明石英いずれの場合も, Fig.4 に示したように気相中の酸素分圧が高くなるにした

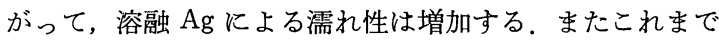
測定されてきた $\mathrm{Fe}-\mathrm{O} / \mathrm{Al}_{2} \mathrm{O}_{3}$ 系 ${ }^{(1)(2)}, \mathrm{Ni}-\mathrm{O} / \mathrm{Al}_{2} \mathrm{O}_{3}$ 系 ${ }^{(5)}$, $\mathrm{Co}-\mathrm{O} / \mathrm{Al}_{2} \mathrm{O}_{3}$ 系 $^{(6)}, \mathrm{Cu}-\mathrm{O} / \mathrm{Al}_{2} \mathrm{O}_{3}$ 系 $^{(3)}{ }^{(4)}, \mathrm{Ni}-\mathrm{O} / \mathrm{MgO}$ 系(19) においても，酸素量の増加にしたがって濡れ性は増加す る.これらのことから，溶融金属による固体酸化物の濡れ 性が, 気相中の酸素分圧または溶融金属中の酸素量の増加 によって増大することは一般的な現象であると考えられ る、しかし，同じカルコゲン族の表面活性元素である， S, $\mathrm{Se}, \mathrm{Te}$ は固体酸化物の濡れ性を増加させず，かえって低 下させる傾向がある(1)(17)(18). したがって, 表面活性元素 がかならずしも溶融金属による固体酸化物の濡れ性を増加 させるとはいえない。つまり，液体と固体間の接触角は液 体の表面張力, 固体の表面張力拉よび固 - 液界面張力の釣 り合いで決定されるため, 表面活性元素が固体酸化物の表 面張力に影響しないと仮定すれば，溶融金属の表面張力の 低下に比べてより大きく溶融金属 - 固体酸化物界面張力が 低下しなければ接触角の低下，すなわち濡れ性の増加は起 こらない，前述したように，表面では酸素は金属酸化物の 形態で吸着するので，固体酸化物との界面でも同様の形態 で吸着するものと考えられる。 S , Se, Te の場合は, 吸着 した硫化物, セレン化物, テルル化物は一般には固体酸化 物と反応しにくい( $\mathrm{FeS}$ の場合は $\mathrm{CaO}$ と反応しやすい) が, 酸素の場合は, 吸着した酸化物が固体酸化物と反応す るため, 反応に伴って激しく界面張力が低下する. このこ
とが酸素が特に溶融金属による固体酸化物の濡れ性を増加 させる原因であると考えられる，実際にこれまで報告され ている例では, $\mathrm{Fe}-\mathrm{O} / \mathrm{Al}_{2} \mathrm{O}_{3}$ 系では $\mathrm{FeAl}_{2} \mathrm{O}_{4}{ }^{(6)}, \mathrm{Ni}-\mathrm{O} / \mathrm{Al}_{2} \mathrm{O}_{3}$ 系では $\mathrm{NiAl}_{2} \mathrm{O}_{4}{ }^{(5)}, \mathrm{Co}-\mathrm{O} / \mathrm{Al}_{2} \mathrm{O}_{3}$ 系では $\mathrm{CoAl}_{2} \mathrm{O}_{4}{ }^{(6)}, \mathrm{Cu}-\mathrm{O} /$ $\mathrm{Al}_{2} \mathrm{O}_{3}$ 系では $\mathrm{CuAlO}_{2}{ }^{(3)}, \mathrm{Ni}-\mathrm{O} / \mathrm{MgO}$ 系では $\mathrm{NiO}-\mathrm{MgO}$ 固溶 体 ${ }^{(19)}$ が反店層として確認されている。 しかし, 本研究の場 合, 溶融 $\mathrm{Ag}-\mathrm{O}$ 合金と透明石英間の冷却後の反応層は銀酸 化物の拡散した層ではなく, $\mathrm{Ag}$ 粒子が $\mathrm{SiO}_{2}$ 基地に分散し た層であった，この反応層の成因については詳しくはわか らないが， $\mathrm{Ag}$ が金属状態のままで $\mathrm{SiO}_{2}$ 中に拡散するとは 考えにくいため, 最初吸着した $\mathrm{Ag}_{2} \mathrm{O}$ が $\mathrm{SiO}_{2}$ と反応し， その後何らかの機構で $\mathrm{Ag}_{2} \mathrm{O}$ が還元されて $\mathrm{Ag}$ が析出し たのであろらと思われる。また， $\mathrm{Al}_{2} \mathrm{O}_{3}$ の場合は，多結晶， 単結晶いずれの場合でも, 測定範囲の酸素分圧下(最高 $\left.5.59 \times 10^{4} \mathrm{~Pa}\right)$ では反応層は認められなかった。しかし Knox と Baker ${ }^{(20)}$ は最高 $2.5 \times 10^{6} \mathrm{~Pa}$ まて酸素分圧を変化 させて溶融 $\mathrm{Ag}$ による単結晶 $\mathrm{Al}_{2} \mathrm{O}_{3}$ の濡れ性を観察した際 に, 反応生成物は同定できなかったが界面に反応層が存在 したことを報告している，したがって酸素分圧をより高く すれば，やはり界面に反応層が生じるようになるものと思 われる。このことは $\mathrm{Ag}_{2} \mathrm{O}$ が $\mathrm{SiO}_{2}$ に比べて $\mathrm{Al}_{2} \mathrm{O}_{3}$ と反応 しにくいことを表わしており，高酸素分圧下では $\mathrm{Al}_{2} \mathrm{O}_{3}$ の 方が濡れにくかった事実とよく対応している。

同じ $\mathrm{Al}_{2} \mathrm{O}_{3}$ の場合でも多結晶 $\mathrm{Al}_{2} \mathrm{O}_{3}$ の方がどの酸素分圧 下でも $20^{\circ} \sim 30^{\circ}$ 高い接触角を示したが，これは表面粗さ の差が原因であると考学られる。一般に固体の表面粗さが 大きくなるほど液体との接触角は高くなると言われてお り, 実際に, 溶融 $\mathrm{Fe} / \mathrm{Al}_{2} \mathrm{O}_{3}$ 系で $\mathrm{Al}_{2} \mathrm{O}_{3}$ の表面粗さの増加 にしたがって接触角は高くなると報告されている(21)。乙 たがって, 多結晶体の場合, 粒界や気孔が存在し, 単結晶 に比べて表面粗さが大きいため全体的に接触角が高くなっ たものと考えられる。

\section{V. 総 括}

溶融 $\mathrm{Ag}$ による固体酸化物の濡れ性に及ぼす酸素の影響 を調べるために，静滴法によって溶融 $\mathrm{Ag}-\mathrm{O}$ 合金の表面張 力および多結晶 $\mathrm{Al}_{2} \mathrm{O}_{3}$, 単結晶 $\mathrm{Al}_{2} \mathrm{O}_{3}$ および透明石英との 接触角を測定した。測定後の試料の付着状況を調べるため に, $\mathrm{Ag}$ と固体酸化物間の界面を EPMA を用いて観察およ び分析を行った，得られた結果を要約すると次のとおりで ある。

（1）酸素は溶融 $\mathrm{Ag}$ の表面張力を微量で著しく低下さ せ，表面活性元素として作用する。

（2）測定から得られた最大表面過剩量は $5.8 \times 10^{-6} \mathrm{~mol}$. $\mathrm{m}^{-2}$ で, この数值から, 酸素は溶融 $\mathrm{Ag}$ 表面に $\mathrm{Ag}_{2} \mathrm{O}$ の形 で吸着するものと考えられ，同族元素である $\mathrm{Cu}$ に対する 挙動と類似している.

(3) 溶融 $\mathrm{Ag}$ による多結晶 $\mathrm{Al}_{2} \mathrm{O}_{3}$ ，単結晶 $\mathrm{Al}_{2} \mathrm{O}_{3}$ および 
透明石英の濡れ性は酸素分圧が高くなるほど増加し, 高酸 素分圧下 $\left(>4 \times 10^{3} \mathrm{~Pa}\right)$ では透明石英が最も濡れやすい.

(4) 測定を行った酸素分圧範囲 $\left(<5.59 \times 10^{4} \mathrm{~Pa}\right)$ では, $\mathrm{Ag}$ と多結晶 $\mathrm{Al}_{2} \mathrm{O}_{3}$ 㧊よび単結晶 $\mathrm{Al}_{2} \mathrm{O}_{3}$ の界面には反応層 は認められなかったが，透明石英との界面には $0.5 \mu \mathrm{m}$ 以 下の微細な $\mathrm{Ag}$ 粒子が分散した層が存在した。

\section{文献}

(1) P.Kozakevitch et G.Urbain : Mém. Sci. Rev. Mét., 58 (1961) , 517.

（2）荻野和巳，野城 清，越田幸男:鉄と鋼， 59 (1973)， 1380 .

(3) A.C.D. Chaklader, A. M. Armstrong and S. K. Misra : J.Amer. Ceram. Soc., 51 (1968) , 630.

(4) T.E.O'Brien and A.C.D.Chaklader : J.Amer. Ceram. Soc., 57 (1974), 329.

（5）荻野和巳，泰松 斉：日本金属学会誌, $43(1979)$, 872 .

（6）荻野和巳, 泰松 斉, 中谷文忠：日本金属学会誌, 46 (1982), 957.

(7) F. Bashforth and S.C.Adams: An Attempt to Test the Theories of Capillary Action, Cambridge University Press, London, (1883).

(8) T.H.Etsell and S.N. Flengas : Met. Trans., 3 (1972) , 27.
（9）泰松 斉，金児紘征，上谷順則，中谷文忠：日本金 属学会誌, 46(1982)，951。

(10) C.H.P.Lupis and J.F.Elliott: Trans. Met. Soc. AIME, 242 (1968), 929.

(11) L. D. Lucas : Physicochemical Measurements in Metals Research, Part 2, Ed. by R.A.Rapp, John Wiley and Son Inc., New York, (1970), 219.

(12) G. Bernard and C.H. P. Lupis : Met. Trans., 2 (1971), 2991.

(13) V.N.Eremenko and Yu.V.Naidich : The Role of Surface Phenomena in Metallurgy, Ed. by V.N. Eremenko, Consultants Bureau, New York, (1963), 65.

(14) 桐山良一, 桐山秀子 : 構造無機化学 I, 第 3 版, 共 立出版，(1979)，108

(15) B.Gallois and C.H.P.Lupis : Met.Trans. B, 12B (1981) , 549.

(16) 門間改三，須藤 一：日本金属学会誌，24 (1960)， 377 .

（17）荻野和巳，野城 清，山瀬 治:鉄と鋼，66(1980), 179 .

(18) K.Nogi and K.Ogino:Can.Met. Quart., 22 (1983), 19

(19) 泰松 斉: 未発表

(20) B.E.Knox and E. H. Baker : J. Mater. Sci., 7 (1972), 476.

（21）荻野和巳，野城 清 : 鉄と鋼, 59 (1973), S112。 